\title{
Learning cheminformatics
}

\author{
Rajarshi Guha ${ }^{1 *}$ (1) and Egon Willighagen ${ }^{2}$ (])
}

Since its inception, the Journal of Cheminformatics has made it a point to highlight novel approaches and best practices in cheminformatics. However, one area that we have not addressed are articles on educational aspects of cheminformatics.

Given the increasing importance of chemical information throughout the practice of chemistry, biology and related fields, we realize that articles that focus on introductory aspects of chemical information and cheminformatics would be beneficial to newcomers to the field, which can range from undergraduate students to experienced chemists coming from experimental subfields of chemistry. But we need not restrict ourselves to "introductory" articles. For example, tutorial style articles that describe a common workflow, using a set of open source tools could be generally useful and would be considered within the scope educational article type. We note that the ACS Journal of Chemical Education (ISSN:00219584) provides a venue for educational articles in chemistry, and while some cheminformatics related articles have been published (e.g. $[1,2])$, we feel that the Journal of Cheminformatics provides a more focused context for cheminformatics specific educational material.

In particular, we have developed a set of guidelines for manuscripts that are intented for the educational category which can be viewed at https://jcheminf.biomedcent ral.com/submission-guidelines/preparing-your-manus cript/educational. We are interested in both expository style and tutorial style articles. The former can include articles that present a a pedagogical view of a pre-existing topic, such as chemical similarity or SMILES \& SMARTS for pattern matching. Other topics could focus on aspects of teaching cheminformatics in a classroom. In particular descriptions of pedagogical experiments with chemical information curricula will be of interest.

Tutorial style articles are also of interest and are meant to be step by step descriptions of specific types of calculations-for example, the article by Voicu et al. [3], describe the use of the rcdk R package [4] to compute a clustering of a compound collection. While this task is a standard operation, it is useful for novices to see the whole process described explicitly from start to end.

A key requirement for educational articles is that they employ freely accessible tools and data, to ensure that the material can be followed by readers with minimal limitations. This is in line with requirements for other article types, but for educational articles we plan on requiring the use of open source tools and reusable data with an open license.

In summary, we believe that there is a need for the educational article type and that such articles will enhance the value of the journal to its readership and more broadly within the cheminformatics community.

\section{Authors' contribution \\ Both authors contributed to the development of the educational article type, and writing of this editorial. Bothauthors read and approved the final manuscript. \\ Competing interests \\ The authors declare that they have no competing interests. \\ Author details \\ ${ }^{1}$ Vertex Pharmaceuticals, 50 Northern Ave, Boston, MA 02210, USA. ${ }^{2}$ Maas- tricht University, Universiteitssingel 50, 6229 ER Maastricht, The Netherlands.}

Published online: 20 January 2020

\footnotetext{
*Correspondence: rajarshi_guha@vrtx.com

${ }^{1}$ Vertex Pharmaceuticals, 50 Northern Ave, Boston, MA 02210, USA

Full list of author information is available at the end of the article
}

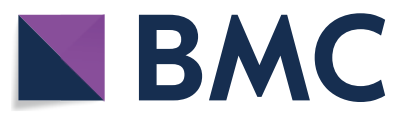

(C) The Author(s) 2020. This article is licensed under a Creative Commons Attribution 4.0 International License, which permits use, sharing, adaptation, distribution and reproduction in any medium or format, as long as you give appropriate credit to the original author(s) and the source, provide a link to the Creative Commons licence, and indicate if changes were made. The images or other third party material in this article are included in the article's Creative Commons licence, unless indicated otherwise in a credit line to the material. If material is not included in the article's Creative Commons licence and your intended use is not permitted by statutory regulation or exceeds the permitted use, you will need to obtain permission directly from the copyright holder. To view a copy of this licence, visit http://creativeco mmons.org/licenses/by/4.0/. The Creative Commons Public Domain Dedication waiver (http://creativecommons.org/publicdomain/ zero/1.0/) applies to the data made available in this article, unless otherwise stated in a credit line to the data. 


\section{References}

1. Pence HE, Williams A (2010) Chemspider: an online chemical information resource. J Chem Educ 87(11):1123-1124. https://doi.org/10.1021/ed100 $697 \mathrm{~W}$

2. Price GW, Gould PS, Marsh A (2014) Use of freely available and open source tools for in silico screening in chemical biology. J Chem Educ 91(4):602-604. https://doi.org/10.1021/ed400302u

3. Voicu A, Duteanu N, Voicu M, Vlad D, Dumitrascu V (2020) The rcdk and cluster R packages applied to drug candidate selection. J Cheminform. https://doi.org/10.1186/s13321-019-0405-0
4. Guha R (2007) Chemical informatics functionality in R. J Stat Softw 18(6):1-6

\section{Publisher's Note}

Springer Nature remains neutral with regard to jurisdictional claims in published maps and institutional affiliations.
Ready to submit your research? Choose BMC and benefit from:

- fast, convenient online submission

- thorough peer review by experienced researchers in your field

- rapid publication on acceptance

- support for research data, including large and complex data types

- gold Open Access which fosters wider collaboration and increased citations

- maximum visibility for your research: over $100 \mathrm{M}$ website views per year

At BMC, research is always in progress.

Learn more biomedcentral.com/submissions 